\title{
High levels of genetic diversity in Penaeus monodon populations from the east coast of India
}

\author{
Gulab Dattarao Khedkar ${ }^{1,4}$, A Chandrashekar Reddy ${ }^{2}$, Tetszuan Benny Ron ${ }^{3}$ and David Haymer ${ }^{*}$
}

\begin{abstract}
Quality production of the shrimp Penaeus monodon in hatchery operations depends heavily on the evaluation of genetic diversity and population structure of brood stocks. Mitochondrial DNA (mtDNA) sequences have been widely used to study genetic variability and relationships in many crustacean groups, and these same markers may be incorporated into evaluation studies of shrimp broods and populations. For this purpose we looked at variation in mitochondrial D-loop sequences as an indicator of genetic diversity in shrimp populations from a region of India that represents the main sources of new material for brood stocks. In our study of these populations the overall mean genetic diversity was 0.191 . The highest level of genetic diversity (0.357) was observed in the Kakinada population, whereas the lowest diversity (0.0171) was observed in the Nellore population. The results also indicate that overall, the populations along the Andhra Pradesh coast are genetically diverse despite the fact that there is considerable gene flow between them. From the results, it is evident that east cost of India shows high genetic diversity among P. monodon broods and no evidence of loss of diversity due to excessive inbreeding. The fact that the genetic variability of these populations has been maintained, despite ten years of dependence on these broods, shows that at the present time there is no indication of over exploitation.
\end{abstract}

Keywords: Penaeus monodon; Population genetics; Hatchery; Mt DNA; Dloop; Diversity

\section{Introduction}

The genus Penaeus represents an economically important group of shrimps and prawns (Dall et al. 1990; BaileyBrook and Mass 1992; Rosenberry 2001). Aquaculturing of Penaeus monodon alone accounts for more than $50 \%$ of the world's cultured shrimp (Ronnback 2001). However, because of limited reproductive capacity in captivity, continued culturing is highly dependent on wild caught brood stocks (Spann et al. 1997). Also, in hatchery operations, the identification and evaluation of comparative growth performance of existing stocks is necessary (Benzie 1994). Hence, basic knowledge about genetic markers, levels of genetic diversity and differentiation in broods and populations is imperative for construction of an appropriate genetic based stock enhancement programme and to identify regions that may be over exploited and where artificial recruitment may be required (Kumar et al. 2007).

\footnotetext{
* Correspondence: dhaymer@hawaii.edu

${ }^{1}$ Department of Cell and Molecular Biology, University of Hawaii, 1960 East-west Rd, Honolulu, HI 96822, USA

Full list of author information is available at the end of the article
}

Mitochondrial DNA (mtDNA) sequences are widely used to study genetic variability in aquaculture species including crustaceans, and these sequences have proved extremely useful in elucidating genetic variability and phylogenetic relationships among many crustacean groups (Cunningham et al. 1992; Chu et al. 2003). These regions may also contain ideal markers for characterizing geographical patterns of genetic variation within and between prawn populations (Simon 1991). The complete mitochondrial genome of P. monodon is around $16 \mathrm{~kb}$ (Wilson et al. 2000), of which $991 \mathrm{bp}$ is the long noncoding, 'AT' rich control region known as the D-Loop. This region plays a significant role in mitochondrial replication and DNA transcription, and it contains the signals that control many general aspects of RNA and DNA synthesis. Previous reports employing mtDNA D-loop based studies on penaeids have demonstrated the usefulness of this region in genetic variability studies (Chu et al. 2003; Tzeng et al. 2004 and Kumar et al. 2007).

Domestication of P. monodon has been carried out for production of high-quality pond-reared $P$. monodon brood stocks (Withyachumnarnkul et al. 1998), but the program 
recently collapsed from a white spot syndrome virus (WSSV) infection. Identification of genetically diverse and geographically differentiated shrimp stocks will be essential for both re-establishing and maintaining effective domestication and breeding programs for $P$. monodon. In addition, over exploitation of $P$. monodon may be avoided by continuous monitoring and possible enhancement through the use of natural populations (Klinbunga et al. 2001).

Along the coast line of the area known as Andhra Pradesh $(974 \mathrm{Km})$, the dominant shrimp culture area in India, shrimp hatcheries are clustered in three areas: Vizag (North Andhra), Kakinada (Central Andhra) and Nellore (South Andhra). Out of 280 P. monodon hatcheries in the country, 148 are located in this region (Andhra Pradesh). These produce 7882 million larvae per year, and this represents approximately $63 \%$ of total seed production in India. Keeping in mind the importance of shrimp culture to the economy and the degree to which success is primarily dependent on the health of the seed and the brood stock, the present work has been conducted to study the genetic structure and diversity of brood stocks from the Andhra Pradesh (A.P.) area in India to ensure the ability to maintain genetically diverse brood stocks for improved production.

\section{Materials and methods Sample collection}

Wild samples of $P$. monodon brooders were collected from the three regions along the A.P. coast (Figure 1). The study area was demarcated into three regions as Vizag (North Andhra), Kakinada (Central Andhra) \& Nellore (South Andhra), where the shrimp hatcheries are clustered. The shrimp broods were collected (30 individuals per population) during January- February, 2011 using mechanised boats having bottom trawl nets specifically designed for shrimp catch. Shrimp caught were washed with clean water and pleopods were dissected and preserved in $95 \%$ ethanol at $-4^{\circ} \mathrm{C}$ until they could be further processed.

\section{Genomic DNA isolation}

Genomic DNA was isolated from pleopods following the method described by Sambrook et al. (2005), and the DNA was diluted to obtain a final concentration of $100 \mathrm{ng} / \mu \mathrm{l}$.

\section{PCR primers}

The primers used here for PCR amplification are $12 \mathrm{~S}$ (F) -5' AAGAACCAGCTAGGATAAAACTTT 3 ' and 1R (R) 5'-GATCAAAGAACATTCTTTAACTAC-3'. These were derived from $\mathrm{Chu}$ et al. (2003) and Yang et al. (2006).

\section{PCR amplification reactions}

The mtDNA control region was amplified in a $25 \mu \mathrm{l}$ reaction volume with a final concentration of $1 \mathrm{X}$ Taq polymerase buffer and $0.6 \mathrm{U}$ of Taq polymerase, $1.5 \mathrm{mM}$ $\mathrm{MgCl}_{2}, 2.5 \mathrm{mM} \mathrm{dNTPs}$ and $1.5 \mu \mathrm{M}$ each primer. The thermal profile for hot-start PCR included initial denaturation at $95^{\circ} \mathrm{C}$ for $5 \mathrm{~min}$, followed by 35 cycles of $20 \mathrm{~s}$ at $94^{\circ} \mathrm{C}, 30 \mathrm{~s}$ at $48^{\circ} \mathrm{C}, 60 \mathrm{~s}$ at $68^{\circ} \mathrm{C}$ and a final extension of $10 \mathrm{~min}$ at $68^{\circ} \mathrm{C}$. The PCR product was purified by treatment with exonuclease and shrimp alkaline phosphatase at $37^{\circ} \mathrm{C}$ for $30 \mathrm{~min}$, and the enzyme inactivation was carried out at $85^{\circ} \mathrm{C}$ for $15 \mathrm{~min}$. Products were cleaned by ethanol precipitation and sequenced using an ABI Prism DNA analyzer 3730 (Applied Biosystems, USA) and the Big dye cycle sequencing kit.

\section{Data analysis}

A total of 81 sequences, each $562 \mathrm{bp}$ in length (on average) from the mtDNA control region, were obtained for analysis. Nine of the original samples with incomplete sequence reads were not included in analysis. The usable sequences were aligned using Bio-edit sequence editor package (Hall 1999), and data analysis was performed using ARLEQUIN version 3.0 (Excoffier et al. 2005) and MEGA 4. The mean nucleotide composition, number of transitions, transversions, indels, number of haplotypes, haplotype diversity (h) and nucleotide diversity ( $p i$ ) values (Nei 1987) were calculated for all the populations. The haplotype data were analysed phylogenetically by the neighbour-joining (NJ) method using MEGA 5.0 and the genetic distance by the Jukes and Cantor (1969). Support for the tree nodes was assessed by the bootstrap method (1000 replicates). The geographical structuring of population was examined by performing analysis of molecular variance (AMOVA) to partition the total genetic variation into its variance component and to produce $\mathrm{F}_{\mathrm{ST}}$ statistics (Weir and Cockerham 1984).

\section{Results}

\section{Genetic diversity and lineages}

The partial mitochondrial control region (D-Loop) sequences of $562 \mathrm{bp}$ in length (average) from 81 individuals (NCBI accession nos. JQ863127 to JQ863216) analyzed here show 43 haplotypes with a value of 14.33 for mean haplotype diversity. The overall Jukes-Cantor estimate of nucleotide diversity $(p i)$ for all of the samples analyzed here is $0.452 \pm 0.1415$, with a mean value for the populations of $0.150 \pm 0.141$. The average number of differences 18.8443 and the total number of segregating sites is 417 (Table 1 ).

The Kakinada population contained the largest number of haplotypes (21) and the highest value overall for haplotype diversity (0.931). This was closely followed by the Vizag population where 14 haplotypes produced a 


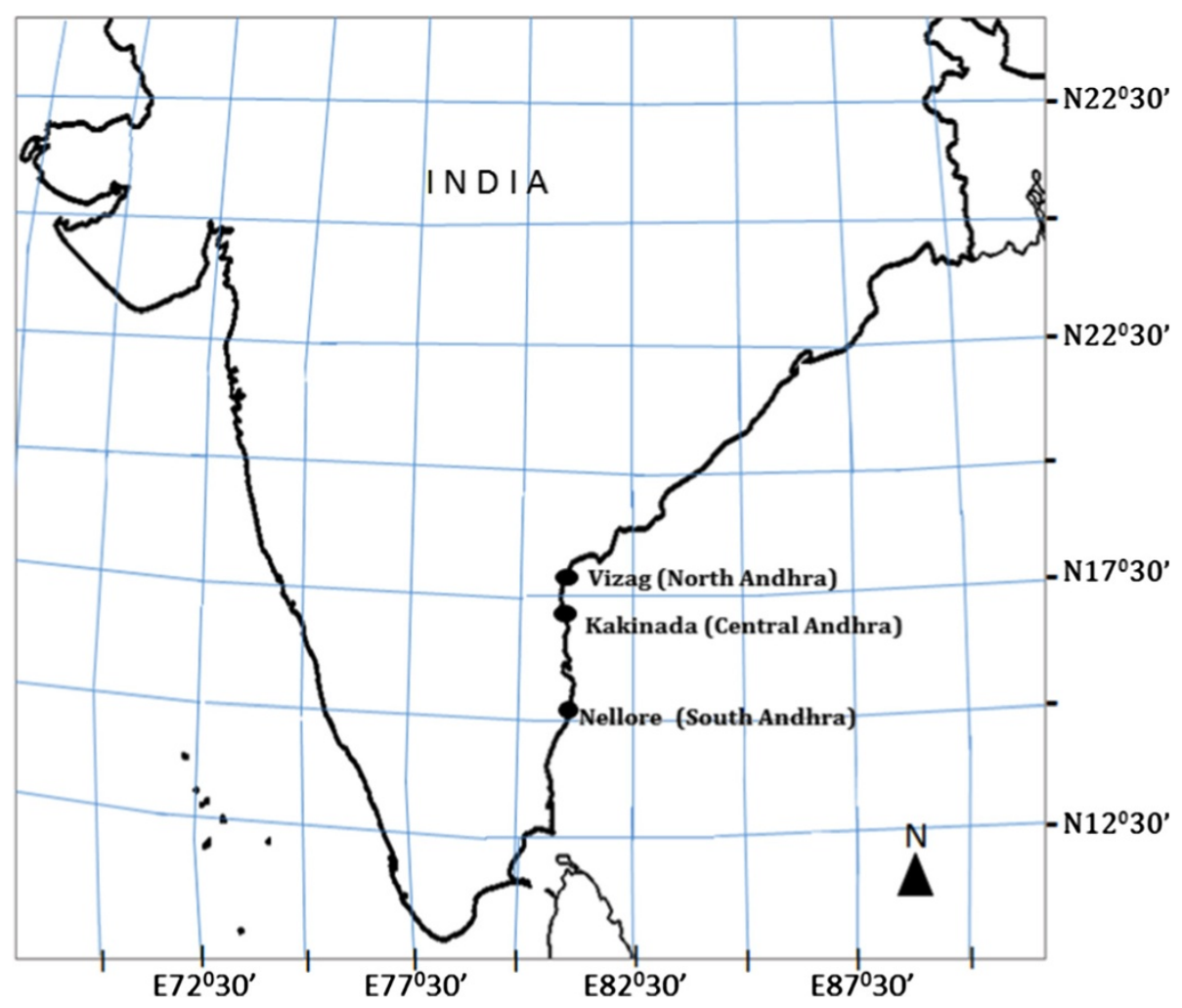

Figure 1 Sampling locations along the East Coast of India.

diversity value of 0.9195 and finally the Nellore population which had 8 haplotypes and a value for haplotype diversity of 0.864 . Most of the haplotypes identified here (42 out of 43) were unique to one of these populations. The one shared haplotype was found in all three of the populations studied here.

Other parameters measuring variation among the three populations are shown in Table 1. A mean expected heterogeneity value of 0.075 was observed among three populations. The individual values ranged from a high of 0.150 in Kakinada to a low of 0.033 in the Vizag population (Table 1). The overall Jukes Cantor (Pi-JC) nucleotide diversity at Vizag population was 0.0350 , Kakinada 0.204 and Nellore was 0.036. The average number of pair wise differences $(k)$ is 17.727 , with the highest number of differences observed in the Kakinada population which was 37.215 and lowest in Vizag (6.386).

\section{Population structure}

For the three populations a total of 417 segregating sites were observed. Also for these populations overall mean numbers of 38 (transition) and 43 (transversion) type substitution mutations were observed. The Kakinada population had the highest numbers of both transitions (74) and transversions (96) whereas lower numbers (22 and 8 , respectively) were seen in the Nellore population. An overall average of 81 substitutions were noted with the least number occuring in the Nellore population (30), followed by 43 in Vizag and the highest in the Kakinada region (170). Indels were absent in all three populations (Table 2).

The overall proportions of nucleotides in this dataset are $0.395(\mathrm{~A}), 0.409(\mathrm{~T} / \mathrm{U}), 0.108(\mathrm{C})$, and $0.088(\mathrm{G})$ based on a total of 286 positions. The transition/transversion rate ratios are $k_{1}=24.707$ (purines) and $k_{2}=31.233$ (pyrimidines). The overall transition/transversion bias is $R=5.623$, where $R=\left[\mathrm{A}^{*} \mathrm{G}^{*} k_{1}+\mathrm{T}^{*} \mathrm{C}{ }^{*} k_{2}\right] /[(\mathrm{A}+\mathrm{G}) *(\mathrm{~T}+$ $\mathrm{C})$ ]. All positions containing gaps and missing data were eliminated.

\section{Population level variation}

An Analysis of Molecular Variance (AMOVA) was performed in MEGA5.0 for 81 sequences to test for geographic variations/divisions among populations. Results from this analysis showed a percentage of variation attributable to among-population differences of $11.04 \%$ whereas most of the variation $(88.96 \%)$ was attributed to variation within populations (Table 3).

The pairwise Fst comparisons in Table 4 show that the Vizag and Nellore populations are the most differentiated whereas the Vizag and Kakinada populations are the least differentiated. Estimates of $\mathrm{Nm}$ to reflect gene 
Table 1 D-loop sequence based diversity analysis

\begin{tabular}{|c|c|c|c|c|c|c|c|c|c|c|c|}
\hline & $\begin{array}{l}\text { No. } \\
\text { of seq. }\end{array}$ & $\begin{array}{l}\text { NCBI accession } \\
\text { numbers }\end{array}$ & $\begin{array}{l}\text { No. of seg. } \\
\text { sites S }\end{array}$ & $\begin{array}{l}\text { No. of } \\
\text { Haplotype }\end{array}$ & $\begin{array}{l}\text { Haplotype } \\
\text { diversity Hd }\end{array}$ & $\begin{array}{c}\text { No. of } \\
\text { polymorphic loci }\end{array}$ & $\begin{array}{c}\text { Expected } \\
\text { heterogenity }\end{array}$ & $\begin{array}{l}\text { Total no. } \\
\text { of alleles }\end{array}$ & $\begin{array}{l}\text { Avg. no. of } \\
\text { differences } \mathrm{K}\end{array}$ & $\begin{array}{c}\text { Avg. no, of } \\
\text { pairwise differences }\end{array}$ & $\begin{array}{l}\text { Nucleotide diversity } \\
\text { with JC Pi-JC }\end{array}$ \\
\hline Vizag & 27 & JQ863127-JQ863156 & 143 & 14 & 0.9195 & 38 & 0.03345 & 1.236 & 11.0022 & 6.386 & $0.035086 \pm 0.01910$ \\
\hline Kakinada & 24 & JQ863157-JQ863186 & 251 & 21 & 0.9310 & 129 & 0.15094 & 1.934 & 40.1207 & 37.215 & $0.204479 \pm 0.102747$ \\
\hline Nellore & 30 & JQ863187-JQ863216 & 23 & 8 & 0.8643 & 47 & 0.03468 & 1.165 & 4.8392 & 6.635 & $0.036457 \pm 0.019701$ \\
\hline \multirow[t]{2}{*}{ Total } & 81 & & 417 & 43 & 2.7148 & & 0.07546 & 2.192 & 90.4458 & 0.3162 & $0.4522 \pm 0.1415$ \\
\hline & & Mean & 139 & 14.33 & 0.9049 & 71.333 & & & 18.8443 & 17.727 & $0.1507 \pm 0.0471$ \\
\hline
\end{tabular}


Table 2 Transition/transversion values

\begin{tabular}{lccccc}
\hline Statistics & Vizag & Kakinada & Nellore & Mean & S.D. \\
\hline No. of transitions & 18 & 74 & 22 & 38.000 & 31.241 \\
No. of transversions & 25 & 96 & 8 & 43.000 & 46.680 \\
No. of substitutions & 43 & 170 & 30 & 81.000 & 77.350 \\
\hline
\end{tabular}

flow between populations are given in Table 5 . The $\mathrm{Nm}$ values between the populations of Vizag and Nellore were relatively lower (3.0486) compared to the highest value of 4.775 seen between the Vizag and Kakinada populations. All of these values, however, are greater than 1 .

A Neighbour Joining (NJ) tree was constructed which depicts the overall relationships of the populations studied here (Figure 2). This tree is divided into two lineages. One contains the Nellore population alone while the second lineage contains both the Vizag and Kakinada populations. This overall lineage relationship is also supported by the Neighbor Joining tree run for all individuals (Additional file 1: Figure S1).

\section{Discussion}

Polymorphisms in mtDNA sequences have been used previously for examining both intraspecific population differentiation and phylogenetic relationships of some penaeid shrimp populations (Benzie 2000; Lavery et al. 2004). This study reports the analysis of genetic variation in the mtDNA D-loop region of P. monodon, a commercially important shrimp species (Bailey-Brook and Mass 1992; Rosenberry 2001), and provides information about the genetic structure and relationships of populations from a region which accounts for the majority (63\%) of brood seed production in India (AISHA-All India Shrimp Hatcheries Association 2004; FAO 2004; 2006). Because this is the largest shrimp producing and seed supplying region in India, a major goal of this study was to provide baseline data for estimates of genetic diversity and population structure of $P$. monodon. Analysis of genetic variability and geographic differentiation of such organisms is essential for the development of effective resource management programs (Avise 1994). This type of information is required for maintaining and improving the culture and management efficiency of $P$. monodon (Carvalho and Hauser 1994; Ward and Grew 1994). In general, relatively low degrees of genetic differentiation have been seen in

Table 3 AMOVA analysis

\begin{tabular}{lcccc}
\hline Source of variation & d. f. & $\begin{array}{c}\text { Sum of } \\
\text { square }\end{array}$ & $\begin{array}{c}\text { Variance } \\
\text { components }\end{array}$ & $\begin{array}{c}\text { Percentage } \\
\text { of variation }\end{array}$ \\
\hline Among population & 2 & 468.44 & 6.154 & 11.04 \\
within populations & 87 & 4312.83 & 49.57 & 88.96 \\
\hline
\end{tabular}

Table 4 Population pairwise FSTs

\begin{tabular}{lccc}
\hline & Vizag & Kakinada & Nellore \\
\hline Vizag & 0.0000 & & \\
Kakinada & 0.05309 & 0.00000 & \\
Nellore & 0.21819 & 0.09555 & 0.00000 \\
\hline
\end{tabular}

wild $P$. monodon, even for those separated over distances of hundreds or thousands of kilometres, except where major biogeographic boundaries act to disrupt gene flow (Benzie et al. 2002).

Among the regions studied here, high levels of mtDNA diversity were observed overall. This is generally consistent with findings from previous studies for decapods and penaeids in general (Silberman et al. 1994; Baldwin et al. 1998; Benzie et al. 2002) although the overall nucleotide and haplotype diversity values obtained in this study are among the highest reported (0.1507 and 0.9049 respectively) for this species. Previously the maximum haplotype diversity reported for P. monodon was $0.682 \pm$ 0.002 (Benzie 2000) and the maximum nucleotide diversity was $0.00334 \pm 0.00003$ (Klinbunga et al. 1998). We obtained haplotype diversity values of $0.9195,0.9310$ and 0.8634 for the Vizag, Kakinada and Nellore populations, respectively. The genetic diversity for the Kakinada population also appears to be greater compared to that of the other populations. The values we obtained for these P. monodon populations are, however, comparable with those derived from mtDNA d-loop region sequences of the black shrimp Caridina cantonesis, the white shrimp Panaeus setiferus, and the pink shrimp Farfantepenaeus duorarum, (McMillenJackson and Bert 2003, 2004; Kumar et al. 2007 and Khamnamtong et al. 2009).

The AMOVA results show that most of the variation (88.96\%) detected here is found within populations. Our results also suggest that overall, high levels of gene flow (as reflected by $\mathrm{Nm}$ values) are occuring between these populations. Nevertheless, as indicated by the pairwise Fst values, the mixing of lineages in P. monodon in India has clearly not been complete. This could be explained by some ecological or environmental factors such as major physical barriers, pollution or reversals in the monsoondriven surface water current systems (Dale 1956). Similar findings were reported by Khamnamtong et al. (2009) and Mandal et al. (2012). Also in Australia (Benzie et al. 2002), low levels of population genetic differentiation in wild $P$. monodon were evident over distances of hundreds or

Table $5 \mathrm{Nm}$ values between populations

\begin{tabular}{lc}
\hline \multicolumn{2}{c}{ Gene flow (Nm) between populations } \\
\hline Vizag and Kakinada & 4.775 \\
Vizag and Nellore & 3.048 \\
Kakinada and Nellore & 3.966 \\
\hline
\end{tabular}



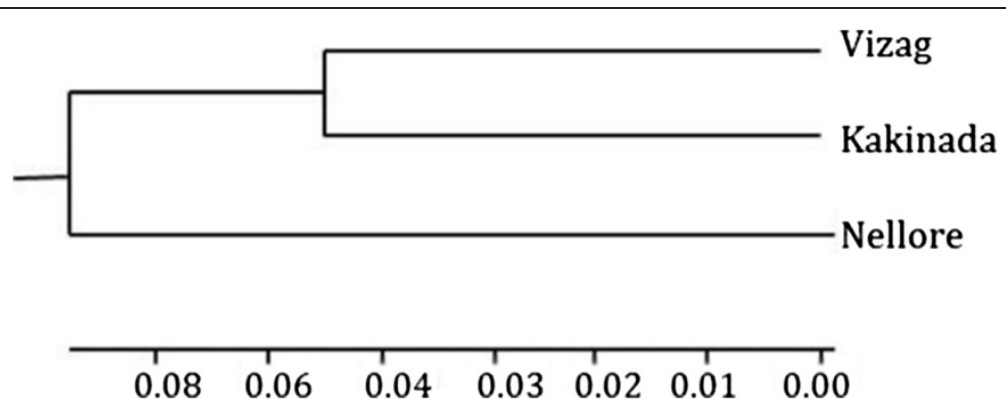

Figure 2 Neighbor joining tree for populations.

thousands of kilometers, except where major biogeographical boundaries acted to disrupt gene flow.

The NJ trees constructed using control region sequence data also showed a general population structuring according to geographical distribution. However, a number of mixed lineage hapolotypes were found at present in each geographic sample, reflecting some secondary mixing of those haplotypes. This may be explained by the fact that the spawning behavior of $P$. monodon females can enhance levels of lineage mixing because they migrate offshore when they grow and mature (Motoh 1981). Regardless, the overall relationships shown by the NJ trees that group the Vizag and Kakinada populations together is again consistent with the apparent high levels of gene flow and relatively low levels of genetic differentiation seen between these two populations as compared to the Nellore populaton.

The levels of genetic diversity revealed in the present study using this mtDNA control region might be useful as genetic indicators for aquaculture purposes including planning for selective breeding, maintaining stock diversity and distinguishing hatchery stocks from the wild populations. Some of this diversity may be explained by a high rate of mtDNA mutation as has been suggested for several other penaeid species (Palumbi and Benzie 1991; Baldwin et al. 1998). The basic knowledge of genetic divergence between evolutionary lineages, and the existence of population differentiation between major stocks of Indian P. monodon, suggests that each population should be treated as a separate management unit because it may display unique demographic and dynamic properties (Carvalho and Hauser 1994; Conover et al. 2006).

The assessment of genetic diversity and population structure of $P$. monodon is critical for appropriate conservation and management purposes. With increased farming and opportunities for future growth in the aquaculture of P. monodon, there is a great concern regarding the loss of wild genetic diversity. For good production, hatchery operators often collect brooders from different parts of the country (AISHA-All India Shrimp Hatcheries Association 2004 and FAO 2006). Similar observations were made by Klinbunga et al. (1998) in Thailand where farmers believe that progeny of the Andaman Sea P. monodon exhibit greater survival and possibly greater growth rates than do progeny from broodstock shrimp caught elsewhere in Thailand. Therefore, genetic monitoring and evaluation of black tiger shrimp can help to identify any negative effects on genetic diversity caused by aquaculture (Naylor et al. 2000; Benzie 2010). Also, maintaining high levels of genetic diversity and population differentiation of $P$. monodon can help to protect this species from disease epidemics and severe population declines. This would further facilitate the stock improvement programme of this commercially important species through selective breeding. The virtual absence of domesticated specific pathogen free stocks of $P$. monodon has inhibited breeding programme development and commercial production of this species (Clifford and Preston 2001). Sourcing and spawning of clean founder stocks from wild populations is one means to generate domesticated pathogen free stocks of $P$. monodon. It is widely accepted that the most economically significant viral pathogens like WSSV, yellow head virus and a host of other pathogens have been introduced into the Asian countries through the careless introduction of live shrimp stocks. Import of disease-free stocks from these regions of India or elsewhere will be beneficial when stocks are used that are free from these and other pathogens and/or viruses.

\section{Conclusions}

Information about genetic variability of critical populations and the potential for improvement using biotechnological applications are crucial for the maintenance and future development of shrimp industry. A high level of genetic diversity has been revealed in the present study using the mtDNA control region. The nucleotide and haplotype diversities obtained in this study are among the highest reported for $P$. monodon populations. The genetic diversity at Kakinada appears to be greater than that of Vizag and Nellore. The relatively high Fst values seen for all of these populations, together with the fact that most of the variation detected here occurs within populations, also indicate that in this region, this species is genetically heterogenous and does not appear to be suffering from 
extensive inbreeding. The genetic diversity seen here suggests that farmers or hatchery operators can continue to use these populations as sources of natural broodstock from this region of India. Finally, the information obtained here may also be useful for providing genetic markers that can be used for aquaculture purposes such as planning for selective breeding, maintaining stock diversity and distinguishing hatchery stocks from the wild populations.

\section{Additional file}

Additional file 1: Figure S1. NJ Phylogenetic tree of all individuals from three populations.

\section{Competing interests}

The authors declare that they have no competing interests.

\section{Authors' contributions}

GD -experimental design, laboratory work, data analysis and manuscript writing. ACR -Collection of stocks, molecular genetic analysis and related laboratory work. TB- Experimental design, data analysis and manuscript writing. DH experimental design, data analysis, and manuscript writing. All authors read and approved the final manuscript.

\section{Acknowledgements}

Authors are thankful to DBT, Government of India for funding this work and to the anonymous reviewers for suggestions to improve this manuscript.

\section{Author details}

${ }^{1}$ Department of Cell and Molecular Biology, University of Hawaii, 1960 East-west Rd, Honolulu, HI 96822, USA. 'State Institute of Fisheries Technology, Jagannayak Pura, Kakinada, Andhra Pradesh, India. ${ }^{3}$ Human Nutrition, Food \& Animal Science, College of Tropical Agriculture \& Human Resources (CTAHR) University of Hawaii At Manoa, 1955 East West Road, AgSci 216, Honolulu, HI 96822, USA. ${ }^{4}$ Paul Hebert Centre for DNA Barcoding and Biodiversity Studies, Dr. Babasaheb Ambedkar Marathwada University, Aurangabad 431004, India.

Received: 1 October 2013 Accepted: 26 November 2013 Published: 13 December 2013

\section{References}

AISHA-All India Shrimp Hatcheries Association (2004) Status of Indian shrimp hatcheries, 7-1-44, Kirlampudi Visakhapatnam - 530023 Andhra Pradesh, India, p 11

Avise JC (1994) Molecular markers, natural history and evolution. Chapman and Hall, New York

Bailey-Brook JH, Mass SM (1992) Penaeid taxonomy, biology and zoogeography. In: Fas WA, Lester $\amalg$ (eds) Marine shrimp culture: principles and practices. Elsevier Science Publishers, Amsterdam, pp 9-23

Baldwin JD, Bass AL, Bowen BW, Clark WH (1998) Molecular phylogeny and biogeography of marine shrimp Penaeus. Mol Phylogen Evol 10:399-407

Benzie JAH (1994) Genetic and reproduction research on giant tiger prawn Penaeus monodon: pond reared spawners achieved in Australia. Aust Biotech 4:222-224

Benzie JAH (2000) Population genetic structure in penaeid prawns. Aqua Res 31:95-119

Benzie JAH (2010) Integration of quantitative and molecular genetics in shrimp breeding. Asian Fisheries Sci 23:497-523

Benzie JAH, Ballment E, Forbes AT, Demetriades NT, Sugama K, Haryanti MS (2002) Mitochondrial DNA variation in Indo-Pacific population of the giant tiger prawn Penaeus monodon. Mol Ecol 11:2553-2569

Carvalho GR, Hauser L (1994) Molecular genetics and the stock concept in fisheries. Rev Fish Biol Fish 4:326-350

Chu KH, Li CP, Tam YK, Lavery S (2003) Application of mitochondrial control region in population genetic studies of the shrimp Penaeus.

Mol Ecol Notes 3:120-122
Clifford HC III, Preston NP (2001) Global Shrimp OP:2001-preliminary report. in: Genetic improvement report. Global Aquat Adv 4:20-26

Conover DO, Clarke LM, Munch SB, Wagner GN (2006) Spatial and temporal scales of adaptive divergence in marine fishes and its implications for conservation. J Fish Biol 69(C):21-47

Cunningham CW, Blackstone NW, Buss LW (1992) Evolution of king crabs from hermit crab ancestors. Nature 355:539-542

Dale WL (1956) Wind and drift currents in the South China Sea Malays J Trop Geogr 8:1-31

Dall W, Hill BJ, Rothlisberg PC, Staples DJ (1990) The biology of Penaeidae. Adv Mar Biol 27:1-484

Excoffier L, Laval G, Schneider S Arlequin (version 3.0) (2005) An integrated software package for population genetics data analysis. Evol Bioinform 1:47-50

FAO (2004) In: Briggs M, Funge-Smith S, Subasinghe RP, Phillips M (eds) Introductions and movement of two penaeid shrimp species in Asia and the Pacific. FAO. Fisheries Technical Paper No. 476, Rome, p 78

FAO (2006) Fisheries and aquaculture software. FishStat Plus - Universal software for fishery statistical time series. FAO Fisheries and Aquaculture Department [online], Rome, http://www.fao.org/fishery/statistics/software/en

Hall TA (1999) BioEdit: a user-friendly biological sequence alignment editor and analysis program for Windows 95/98/NT. Nucleic Acids Symp Ser 41:95-98

Jukes TH, Cantor CR (1969) Evolution of protein molecules. In: Munro HN (ed) Mammalian Protein Metabolism. Academic Press, New York, pp 21-132

Khamnamtong B, Klinbunga S, Menasveta P (2009) Genetic diversity and geographic differentiation of the giant tiger shrimp (Penaeus monodon) in Thailand analyzed by mitochondrial $\mathrm{COI}$ sequences. Biochem Genet 47:42-55

Klinbunga S, Penman DJ, McAndrew BJ, Tassanakajon A, Jarayabhand P (1998) Genetic variation, population differentiation, and gene flow of the giant tiger shrimp (P. monodon) inferred from mtDNA RFLP data. In: Flegel TW (ed) Advances in Shrimp Biotechnology. National Center for Genetic Engineering and Biotechnology, Bangkok, Thailand, pp 51-59

Klinbunga S, Siludjai D, Wuthijinda W, Tassanakajon A, Jarayabhand P, Menasveta $P$ (2001) Genetic heterogeneity of the giant tiger shrimp (Penaeus monodon) in Thailand revealed by RAPD and mtDNA-RFLP analyses. Mar Biotechnol 3:428-438

Kumar N, Lakra WS, Majumdar KC, Goswami M, Ravinder K (2007) Genetic diversity in the Indian population of Penaeus monodon (Fabricius 1798) as revealed by mtDNA sequence analysis. Aqua Res 38:862-869

Lavery S, Chan TY, Tam YK, Chu KH (2004) Phylogenetic relationships and evolutionary history of the shrimp genus Penaeus s.l. derived from mitochondrial DNA. Mol Phylogene Evol 31:39-49

Mandal A, Rao D, Karuppaiah D, Gopalakrishnan A, Pozhoth J, Samraj YC, Doyle RW (2012) Population genetic structure of Penaeus monodon, in relation to monsoon current patterns in Southwest, East and Andaman coastal waters of India. Gene 491(2):149-157

McMillen-Jackson AL, Bert TM (2003) Disparate patterns of population genetic structure and population history in two sympatric penaeid species in the Southeastern United States. Mol Ecol 12:2895-2905

McMillen-Jackson AL, Bert TM (2004) Genetic diversity in the mtDNA contro region and population structure in the pink shrimp Farfantepenaeus duorarum. J Crustac Biol 24:101-109

Motoh H (1981) Studies on the fisheries biology of the giant tiger prawn, Penaeus monodon in the Philippines. Technical paper no. 7, Aquaculture Department, Southeast Asian Department Center, Iloilo

Naylor RL, Golfberg RJ, Primavera JH, Kautsky N, Beveridge MCM, Clay J, Folke C, Lubchenco J, Mooney H, Troell M (2000) Effect of aquaculture on world fish supplies. Nature 405:1017-1024

Nei M (1987) Molecular Evolutionary Genetics. Columbia University Press, New York, NY, USA

Palumbi SR, Benzie JAH (1991) Large mitochondrial differences between morphologically similar penaeid shrimp. Mol Mar Biol Biotechnol 1:27-34

Ronnback P (2001) Shrimp aquaculture - State of the art. Swedish EIA Centre, Report 1. Swedish University of Agricultural Sciences (SLU), Uppsala, ISBN 91-576- 6113-8

Rosenberry B (2001) World shrimp farming 2000. In: Rosenberry B (ed) Shrimp News International, USA. Shrimp News International, San Diego, CA, USA, p 324

Sambrook J, Fristisch EF, Maniatis T (2005) Molecular Cloning - A Laboratory Manual, 2nd edn. Cold Spring Harbor Laboratory Press, Cold Spring Harbor, NY, USA, pp 6.4-6.12 
Silberman JD, Sarver SK, Walsh PJ (1994) Mitochondrial DNA variation and population structure in the spiny lobster Panulirus argus. Mar Biol 120:601-608

Simon C (1991) Molecular systematics at the species boundary: exploiting conserved and variable regions of the mitochondrial genome of animals via direct sequencing from amplified DNA. In: Hewitt GM, Johnston AWB, Young JPW (eds) Molecular Techniques in Taxonomy. Springer-Verlag, New York

Spann KM, Cowley JA, Walker PJ, Lester RJG (1997) A yellow-head-like virus from Penaeus monodon cultured in Australia. Dis Aqua Organ 31:169-179

Tzeng TD, Yeh SY, Hui CF (2004) Population genetic structure of the Kuruma Prawn (P. Japonicus) in East Asia inferred from Mt. DNA sequences. ICES J Mar Sci 61:913-920

Ward RD, Grew PM (1994) Appraisal of molecular genetic technique in fisheries. Rev F Biol Fish 4:300-325

Weir BS, Cockerham CC (1984) Estimating F statistics for the analysis of population structure. Evolution 38:1358-1370

Wilson K, Cahill V, Ballment E, Benzie J (2000) The complete sequence of the mitochondrial genome of the crustacean Penaeus monodon: are malacostracan crustaceans more closely related to insects than to branchiopods? Mol Biol Evol 17:863-874

Withyachumnarnkul B, Boonsaeng W, Flegel TW, Panyim S, Wongteerasupaya C (1998) In: Felgel T (ed) Domestication and selective breeding of Penaeus monodon in Thailand. Proceedings to the special session on advances in shrimp biotechnology, fifth Asian fisheries forum: international conference on fisheries and food security beyond the year 2000, Chiang Mai, Thailand, pp 73-77

Yang B, Song XL, Huang J, Shi CY, Liu QH, Liu L (2006) A single-step multiplex PCR for simultaneous detection of white spot syndrome virus and infectious hypodermal and haematopoietic necrosis virus in penaeid shrimp. J Fish Dis 29:301-305

doi:10.1186/2193-1801-2-671

Cite this article as: Khedkar et al:: High levels of genetic diversity in Penaeus monodon populations from the east coast of India. SpringerPlus 2013 2:671.

\section{Submit your manuscript to a SpringerOpen ${ }^{\circ}$ journal and benefit from:}

- Convenient online submission

- Rigorous peer review

- Immediate publication on acceptance

- Open access: articles freely available online

- High visibility within the field

- Retaining the copyright to your article 